\title{
TARPTAUTINIO SERVITUTO PRIPAŽINIMAS TARPTAUTINIŲ IR NACIONALINIŲ TEISMŲ SPRENDIMUOSE
}

\author{
Inga Griškevičienè \\ Mykolo Romerio universiteto Teisès fakulteto \\ Tarptautinès ir Europos Sąjungos teisès institutas \\ Ateities g. 20, 08303 Vilnius, Lietuva \\ Telefonas (+370 5) 2714669 \\ Elektroninis paštas testi@mruni.eu \\ Pateikta 2012 m. kovo 6 d., parengta spausdinti 2013 m. spalio 24 d. \\ doi:10.13165/SMS-13-5-4-14 \\ Anotacija. Tarptautinio servituto kaip tarptautines teises instituto egzistavimas \\ kelia nemažai klausimų. Šiuolaikinèje tarptautinèje teisèje daugelis tarptautinès teisès \\ mokslininku pripažista toki reiškini kaip tarptautinis servitutas, tačiau nagrinejjant jo \\ pritaikymą teismu praktikoje ryškẻja, kad šio tarptautinès teisès instituto pripažinimas yra \\ neaiškus. Šiame straipsnyje yra nagrinèjami kai kurie nacionaliniai ir tarptautiniai teismu \\ sprendimai, kuriuose teismai sprende klausima del tarptautinio servituto pripažinimo, pa- \\ teikiama šio straipsnio autorès nuomonè dèl ju pripažinimo / nepripažinimo argumentų.
}

Reikšminiai žodžiai: tarptautinis servitutas, tarnaujanti valstybè, dominuojanti valstybè, teise in rem. 


\section{Ivadas}

Šio straipsnio tyrimo objektas - tarptautinio servituto kaip tarptautinès teisès instituto ịtvirtinimas ir jo pripažinimas kaip teisinès kategorijos tarptautiniuose bei nacionaliniuose teismų sprendimuose. Šios temos aktualumą lemia tai, kad Lietuvos Respublikos teritorijoje yra nustatytas tarptautinis servitutas ir jis palankus Rusijos Federacijos interesams, t. y. per Lietuvos Respublikos teritoriją vyksta Rusijos piliečiai, gabenami kroviniai bei vykdomas karinis tranzitas iš Rusijos Federacijos ị Kaliningrado sritị ir iš Kaliningrado srities ị Rusijos Federaciją.

Šiuolaikinèje tarptautinèje teisèje neabejojama, kad tarptautinis servitutas kaip tarptautinès teisès institutas egzistuoja šiuolaikinëje tarptautinèje teisèje, nepaisant to, kad šią sąvoką tarptautinès teisès mokslininkai vis dar laiko kontroversiška. Tarptautinis servitutas aktualiausias buvo XX a., kai po kilusių karų buvo perbraižomas pasaulio žemėlapis ir dalijamasi teritorijomis. Nenuostabu, kad šiuo laikotarpiu tarp valstybių kilo daugiausia tarptautinių ginčų. Juos sprendè tarptautiniai teismai, arbitražai ir kitos institucijos, o šią teisinę kategoriją nagrinëjo tarptautinès teisès mokslininkai. Šiame straipsnyje autorė nagrinejja tris tarptautinius ir du nacionalinius teismų sprendimus, kuriais siekiama atskleisti tarptautinio servituto pripažinimą. Autore pasirinko nagrinèti šiuos tarptautinių teismų sprendimus: 1910 m. North Atlantic Coast Fisheries bylą, 1923 m. SS „Wimbledon“ bylą, $1960 \mathrm{~m}$. Right of Passage over Indian Territory bylą ir šiuos nacionalinius teismų sprendimus: 1914 Dutch State Servitude in Prussia bylą ir $1990 \mathrm{~m}$. Union of India v. Sukumar Sengupta bylą. Reikia pažymèti, kad tarptautinio servituto klausimas sprendžiamas ir kitose tarptautinių teismų bylose, tačiau šios bylos pasirinktos todèl, kad jose priimtais sprendimais ar argumentais teismai remiasi nagrineddami kitas bylas. Dvi nacionalinių teismų bylos pasirinktos todèl, kad jose buvo pripažintas tarptautinio servituto egzistavimas. Reikia pažymèti, kad né viena tarptautinè teisminè institucija savo sprendimuose nepripažino tarptautinio servituto, tačiau du nacionaliniai teismai savo sprendimuose ji pripažino kaip neišvengiamą būtinybę egzistavusiomis tos bylos aplinkybèmis.

Tyrimo tikslas - atskleisti tarptautinių ir nacionalinių teismų sprendimų argumentus, kuriais pripažįstamas / nepripažistamas tarptautinio servituto instituto egzistavimas. Atliekant šį tyrimą taikyti ̨̨vairūs moksliniai metodai, pagrindiniai iš jų lingvistinė, dokumentų (šaltinio turinio), loginè, sisteminè, lyginamoji analizè.

\section{Tarptautinių teismų argumentai nepripažįstant tarptautinio servituto egzistavimo}

Pirmoji byla, kurioje buvo nagrinètas tarptautinio servituto institutas ir kurioje aiškiai buvo pateikti argumentai nepripažįstant tarptautinio servituto egzistavimo, yra North Atlantic Coast Fisheries byla (1910 m.). Ginčas tarp Didžiosios Britanijos ir Jungtinių Amerikos Valstijų kilo dèl 1818 metų sutarties taikymo, kuria buvo reguliuojama žvejyba Jungtinių Amerikos Valstijų gyventojams tuometiniuose britų valdomuose Šiaurès Ame- 
rikos vandenyse. Ši sutartis nustatė, kad Jungtinių Amerikos Valstijų gyventojai turi laisvę žvejoti Niufaundlendo ir Kanados vandenyse ${ }^{1}$.

Nuolatinis arbitražo teismas Hagoje (toliau - Teismas) sprendè kelis klausimus, tačiau su tarptautiniu servitutu buvo susijęs pirmasis klausimas, t. y. kokia apimtimi ginčas yra pagristas. Ǐ šio klausimo kilo dar du klausimai, kuriuos reikèjo išspręsti:

1. Ar Didžioji Britanija ir jos kolonijos (Kanada ir Niufaundlendas) pagristai turi teisę reguliuoti žvejybos laisvę, nustatytą 1818 metų sutartyje?

2. Ir, jei tokia teisè egzistuoja, ar šią teisę gali igyvendinti Didžioji Britanija be Jungtinių Amerikos Valstijų sutikimo ir pritarimo?²

Jungtinès Amerikos Valstijos teigè, kad žvejybos laisvių suteikimas Jungtinių Amerikos Valstijų gyventojams Didžiajai Britanijai priklausančiuose vandenyse sudaro tarptautinị servitutą, nes ši laisvè Jungtinių Amerikos Valstijų gyventojams buvo suteikta „amžinai" ir vienašališkai, todèl ji negali būti reguliuojama vietiniais teisès aktais. Iš to darytina išvada, kad Didžiosios Britanijos kaip tarnaujančios valstybės suverenitetas yra suvaržytas ir todèl Didžioji Britanija prarado teisę reguliuoti žvejybą dèl to, kad ją suteikẻ Jungtinèms Amerikos Valstijoms ${ }^{3}$. Didžioji Britanija nesutiko su Jungtinių Amerikos Valstijų argumentais del tarptautinio servituto egzistavimo.

Teismas atmetė Jungtinių Amerikos Valstijų argumentus dèl tarptautinio servituto egzistavimo, vadovaudamasis šiais pagrindiniais argumentais:

1. Nebuvo pateiktas joks įrodymas, kad Jungtinių Amerikos Valstijų ar Didžiosios Britanijos pareigūnai derybų dẻl 1818 metų sutarties metu būtų rèmęsi tarptautinio servituto doktrina.

2. Servitutu tarptautinèje teisèje yra aiškiai suteikta suvereni teisè ir apima santykius tarp proedium dominans ir proedium serviens; pagal 1818 metų sutartị viena valstybé suteikè laisvę žvejoti kitos valstybès gyventojams, tačiau tai nèra suvereni teisė, o tiktai ekonominè teisè.

3. Tarptautinio servituto doktrina iš esmès, kaip dabar yra aiškinama, kilo ypatingomis ir dabar jau pasenusiomis sąlygomis, kurios galiojo Šventosios Romos Imperijos laikais. Tuomet domini terrae nebuvo visiškai suverenios. Jos valde tam tikras teritorijas priklausomai nuo Šventosios Romos Imperijos. Šios teritorijos domini terrae priklausė teoriškai, bet kai kuriais atvejais ir praktiškai, pavyzdžiui, kai reikèdavo ginčą spręsti Šventosios Romos Imperijos teismuose; jų teisés buvo labiau civilinès nei viešosios teisès prigimties ir labiau turèjo dominium nei imperium bruožų. Dèl šių priežasčių domini terrae neturèjo visiško suvereniteto. Šis kvazisuverenitetas, kuris igijo tarpusavyje nesusijusių atributų skirtingais laikotarpiais, savo esme nepablogino tarptautinio servituto doktrinos ir visais atvejais suteikè pranašumą kitai teritorijai ir jos valdytojui, turinčiam visišką suverenitetą. Šiuolaikinės valstybės, ypatingai Didžioji Britanija, niekada nesutiko su suve-

1 Richards, E. The North Atlantic Coast Fisheries Arbitration. Journal of the Society of Comparative Legislation. 1910, 11(1): 19.

2 North Atlantic Coast Fisheries Tribunal of Arbitration constituted under a Special Agreement signed at Washington, January 27th, 1909, between the United States of America and Great Britain. Permanent Court of Arbitration, The Hague, 1910 [interaktyvus]. [žiūrèta 2011-04-05]. $<$ http://www.pca-cpa.org $>$.

Ibid. 
reniteto dalies turejimu dèl to, kad jų konstitucijose reikalaujama, kad šiuolaikinès valstybès turètų pagrindinius dalykus - suverenitetą ir nepriklausomybę.

4. Kadangi ši doktrina mažai susijusi su suvereniteto principu, kuris vyrauja valstybėse, turinčiose konstitucinio valdymo sistemą, pavyzdžiui, Didžiojoje Britanijoje ir Jungtinès Amerikos Valstijose, ir, vystantis suverenių valstybių šiuolaikiniams tarptautiniams santykiams, mažai remiama šiuolaikinių tarptautinès teisès specialistų, todèl Teismas nepatvirtino šios doktrinos. Teismas galèjo patvirtinti tarptautinio servituto doktriną, jei būtų pateiktas aiškus tarptautinès sutarties įrodymas, tačiau, atsižvelgdamas ị bendrus tarptautinès bendrijos interesus ir šios sutarties šalis, Teismas to nepadarè.

5. Jei žvejybos laisvè sukuria tarptautinị servitutą, tuomet tarptautinis servitutas suvaržo tarnaujančios valstybės suverenitetą tik tiek, kiek tarnaujančios valstybès igyvendinamos suverenios teisès yra priešingos dominuojančios valstybės igyvendinamai servituto teisei. Akivaizdu, kad kiekviena žvejybos reguliavimo taisyklè nustato tam tikrus žvejybos apribojimus. Nors šios taisyklès yra pagrịstos ir skirtos apsaugoti žvejybą bei ígyvendinamos siekiant apsaugoti bendruosius interesus, tačiau turi būti aiškiai atskirtos nuo tokių draudimų, kurie negali būti suderinami su servitutu ${ }^{4}$.

Tarptautinès teisès profesorius B. A. Boczekas pažymi, kad, sprendžiant klausimą dèl tarptautinio servituto egzistavimo, Teismo argumentai menkai vertinami šiuolaikinèje tarptautinejje teisejje ir labai mažai tiko šiuolaikinių suverenių valstybių sistemose ${ }^{5}$.

Autorès nuomone, Teismas nepateikè jokių svarių argumentų paneigdamas tarptautinio servituto egzistavimą šioje situacijoje. Autorès nuomone, pirmasis Teismo tarptautinio servituto nepripažinimo pagrindas yra visiškai nepagrịstas, nes tarptautinio servituto egzistavimas nepriklauso nuo to, ar sutarties šalys derybų metu ji tiesiogiai ịvardijo, ar ne. Tarptautinio servituto egzistavimas priklauso nuo to, ar galima įvardinti jo požymius, ar ne. Autorẻ savo straipsnyje „Tarptautinio servituto pripažinimas tarptautinèje teisèje ${ }^{\text {“6 }}$ išskyrè tokius tarptautinio servituto požymius:

1. Pastovumas arba ilgalaikiškumas.

2. Dviejų arba daugiau valstybių dalyvavimas.

3. Atsiradęs tarptautinès sutarties arba kitu pagrindu.

4. Vienos valstybės teisių igyvendinimas („viešpataujanti teritorija“ - territorium dominans) kitos valstybès visoje teritorijoje arba jos dalyje („tarnaujanti teritorija“ - territorium serviens) arba viena valstybė yra ịpareigota („tarnaujanti teritorija“ - territorium serviens) kitai ar kitoms valstybèms („viešpataujanti teritorija“ - territorium dominans) neigyvendinti tam tikrų savo teisių visoje savo teritorijoje arba jos dalyje.

5. Atsiradęs dèl specialaus tikslo arba interesų, susijusių su teritorija.

Taigi šiuo atveju yra aiškūs tarptautinio servituto subjektai, t. y. Jungtinès Amerikos Valstijos - dominuojanti valstybè, arba kitaip tariant, naudos gavejja, ir Didžioji Britanija - tarnaujanti valstybè. Tarptautinio servituto objektas buvo 1818 metų sutartimi nustatyti Kanados ir Niufaundlendo vandenys, o jo turinys - ta pačia sutartimi nustatyta

5 Boczek, B. A. International Law - A Dictionary. USA: Scarecrow Press, 2005, p. 247.

6 Griškevičienè, I. Tarptautinio servituto institutas tarptautinèje teisèje: teoriniai aspektai. Socialinių mokslų stuidijos. 2011, 3(4): 1461-1477. 
laisvè žvejoti Jungtinių Amerikos Valstijų gyventojams. Ši laisvè egzistavo gana seniai, t. y. Teismas pažymèjo, kad ji atsirado 1783 metais, o veliau pakartota 1818 metų sutartyje, todèl tarptautinị servitutą galima ịvardinti kaip ilgalaikị ir pastovų. Tarptautinis servitutas turi ir ketvirtąji požymį, t. y. Jungtinès Amerikos Valstijos iggyvendino suteiktą žvejybos laisvę Didžiajai Britanijai priklausiusiuose vandenyse. Be abejo, ši laisvè yra susijusiu su specialiu tikslu, t. y. pagauti žuvies.

Taip pat autorè, kaip ir daugelis kitų tarptautinès teisės mokslininkų, nesutinka su Teismo nuomone, kad tarptautinis servitutas mažai susijęs su suvereniteto principu ir mažai remiamas šiuolaikinių tarptautinès teisès mokslininkų. Tarptautinis servitutas yra netgi labai susijęs su suvereniteto principu, nes tik suvereni valstybė gali suteikti tam tikras teises kitai suvereniai valstybei. Autorè sutinka, kad tuo metu, kai buvo nagrinëjama ši byla, gal ir nebuvo pakankamai teisės šaltinių, kuriuose būtų nagrinèjamas tarptautinis servitutas, tačiau Teismui prièmus šį sprendimą šiuo tarptautinès teisès institutu susidoméjo daug tarptautinès teisès mokslininkų.

Žvejybos laisvę Teismas ịvardijo kaip ekonominę, o ne suverenią teisę, tačiau nepaaiškino kodèl. Kai kurios tarptautinį servitutą sudarančios teisès, kaip, pavyzdžiui, tranzito teisè, taip pat gali būti susijusi su ekonominiais interesais, tačiau ji taip pat bus valstybès suvereni teisè.

Taip pat negalima sutikti su Teismo argumentu, kad tarptautinis servitutas apriboja tarnaujančios valstybès suverenitetą bei kartu ir suverenias teises. Vèlesnėse bylose, pavyzdžiui, SS „Wimbledon“ byloje, Nuolatinis Tarptautinis Teisingumo Teismas pažymejjo, kad „savo išvadoje Teismas nesutinka, kad bet kuri sutartis, pagal kurią valstybė yra ipareigota atlikti tam tikrus veiksmus arba susilaikyti nuo jų, yra suvereniteto apribojimas. Jokios abejonès, kad bet kokia sutartis, nustatanti tokio pobūdžio ịsipareigojimus, kurie riboja valstybės suverenių teisių ịgyvendinimą, reikalauja, kad būtent tokiu būdu jie būtų igyvendinti. Tačiau teisè tapti tarptautinio susitarimo dalyviu yra tarptautinio suvereniteto požymis" ${ }^{\text {“7 }}$.

Atsižvelgdama ị išdèstytus argumentus, autorè mano, kad žvejybos laisvių suteikimas Jungtinių Amerikos Valstijų gyventojams Didžiajai Britanijai priklausančiuose vandenyse sudaro tarptautinị servitutą.

Kita byla, susijusi su atsisakymu pripažinti tarptautinị servitutą esamomis aplinkybèmis. SS „Wimbledon“ byloje (1923 m.) Prancūzija, Italija, Japonija ir Didžioji Britanija padavė Vokietiją i̇ Nuolatinị Tarptautinị Teisingumo Teismą (toliau - Teismas), nes ji atsisakè praleisti anglų garlaivị „Wimbledon“, gabenantị karinę amuniciją Lenkijai per Kylio kanalą į Gdansko miestą. Lenkija tuo metu kariavo su Rusija. Vokietija neatsižvelgè ị tai, kad 1919 metų Versalio taikos sutarties 380 straipsnis nustate, kad „Kylio kanalas ir jo prieigos privalo būti išlaikyti laisvi ir atviri visų tautų komerciniams ir karo laivams taikos su Vokietija metu ir jais naudotis visiškai lygiomis sąlygomis"8.

Vokietija savo atsisakymą praleisti minètą garlaivị grindè tuo, kad neutraliteto įsakymai, išleisti 1920 m. liepos 25 ir 30 dienomis, yra susiję su Lenkijos ir Rusijos karu,

7 Case of the SS „Wimbledon“, P.C.I.J., ser. A, No. 1, 1923.

8 Kelsen, H. Principles of International Law. 5 th ed., New Jersey: The Lawbook Exchange Ltd, 2003, p. 346. 
kurie ir uždraudè tranzitu gabenti tokios rūšies krovinius. Vokietijos $1920 \mathrm{~m}$. liepos $25 \mathrm{~d}$. neutraliteto ísakymo 1 straipsnis nustatè, kad „Ginklų, amunicijos, parako, sprogmenų ir kitų karui naudojamų medžiagų eksportas ir tranzitas yra draudžiamas tiek, kiek tai susiję su jų gabenimu ị Lenkijos teritoriją ar Sovietų Sąjungos teritoriją“. Vokietija taip pat argumentavo, kad Versalio taikos sutarties 380 straipsnis neužkerta kelio taikyti šiuos neutraliteto ísakymus Kylio kanalui ${ }^{9}$.

Iškilo klausimas, ar Vokietija turèjo teisę neleisti anglų garlaiviui kirsti Kylio kanalo, kai Vokietija buvo neutrali ir tvirtino, kad, leisdama šiam garlaiviui kirsti Kylio kanalą, ji pažeis neutralitetą ${ }^{10}$.

Teismas nagrinejo Versalio taikos sutarties 380 straipsnị dèl Kylio kanalo teisinio statuso. Teismas mano, kad sąlygos, nustatytos Versalio taikos sutarties 380 straipsnyje, yra kategoriškos ir nekelia jokių abejonių. Iš to darytina išvada, kad kanalas nustojo būti vidaus vandenimis ir nacionaliniu navigacijos vandens keliu. Jo naudojimosi teisé visiškai palikta valstybės, kurios laivas naudojasi šiuo kanalu, nuožiūrai. Kylio kanalas tapo tarptautiniu vandens keliu, kuriuo pagal Versalio taikos sutartị numatyta garantuoti lengvesnị patekimą i Baltijos jūrą visų pasaulio tautų laivams, neišskiriant karo nei komercinių laivų. Čia galioja viena sąlyga, kad tarp tautos, kurios laivas plaukia Kylio kanalu, ir Vokietijos turi būti taika ${ }^{11}$. Be to, vienašališkas teisės aktas negali būti viršesnis už Versalio taikos sutarties nuostatas ${ }^{12}$.

Norint įrodyti, jog SS „Wimbledon“ byloje egzistavo teisè į laisvą plaukimą per Kylio kanalą vadovaujantis Versalio taikos sutarties 380 straipsnio sąlygomis, reikejjo ịtikinti Teismą, kad ši teisè iš tikrųų prilyginama servitutui pagal tarptautinę teisę, kuri priklauso Vokietijai. Taip pat reikejo įrodyti, kad reikalingi visi draudimai ir apribojimai, susiję su suvereniteto igyvendinimu, todèl šis servitutas privalo būti interpretuojamas kiek įmanoma griežčiau ir siauriau, ypatingai tais atvejais, kad jis negalètų daryti itakos teisems, kylančioms iš neutraliteto karinių konfliktų metu. Teismo nebuvo prašoma priimti aiškios nuostatos klausimu, ar tarptautinès teisès srityje iš tikrųjų egzistuoja servitutas, analogiškas servitutui privatineje teiseje. Visais atvejais, ar Vokietijos vyriausybè yra apribota servitutu, ar sutartiniu ịsipareigojimu suteikti teisę laisvai perplaukti Kylio kanalą visų tautų laivams karo ar taikos metu pagal Versalio taikos sutarties nuostatas, faktas lieka tas, kad Vokietija privalo paklusti Versalio taikos sutarties nuostatoms, nepaisant to, kad niekas neabejoja, jog Kylio kanalą valdo Vokietija. Teismas jautėsi ịpareigotas griežčiau neinterpretuoti straipsnio, nes kitu atveju tolesnẻ interpretacija būtų priešinga straipsnio esmei ir panaikintų tai, kas jau yra nustatyta ${ }^{13}$.

Teismas padarè išvadą, kad Vokietija būdama neutrali pažeidè savo įsipareigojimą ir privalèjo praleisti „Wimbledon“ laivą. Versalio taikos sutarties 380 straipsnis aiškiai api-

9 Feinaugle, C. The Wimbledon. 2008, Max Planck Encyclopedia of Public International Law [interaktyvus]. [žiūrèta 2011-02-01]. < http://www.mpepil.com/>.

10 McNair, A. D. So-Called State Servitudes. British Year Book of International Law 6 Brit. Y. B. Int'l L. 111, 1925, p. 115.

11 Supra note 7,25 para.

12 Feinaugle, C., op. cit.

13 Supra note 7, 34 para. 
brèžè jos pareigą. Vokietija negalèjo remtis savo neutraliteto ịsakymais dèl ịsipareigojimų, kuriuos prisiemè pagal Versalio taikos sutarties 380 straipsni ${ }^{14}$.

Taigi Teismas paliko atvirą klausimą, ar teisè ị laisvą plaukimą per Kylio kanalą apima servitutą. Jis ịrodinèjo, kad paprastas sutartinis ịsipareigojimas turi būti aiškinamas siaurai, kadangi kitu atveju apribos Vokietijos suverenias teises. Teismas laikèsi Versalio taikos sutarties 380 straipsnio, nes kitu atveju Vokietijos ịsipareigojimai būtų bereikšmiai. Galiojanti teisè ị laisvą plaukimą nereiškia, kad Vokietija netenka savo suverenių teisių kaip neutrali valstybè, o atvirkščiai, igyvendina savo suverenias teises. Tarptautinė praktika, atsižvelgiant $\mathfrak{i}$ Sueco ir Panamos kanalų naudojimo teisinị reguliavimą, rodo, kad naudojimasis tarptautiniais vandens keliais nèra nesuderinamas su pakrantès suvereno neutralitetu. Taisyklès, nustatytos šių kanalų reguliavimui, yra nustatomos visam pasauliui, kad valstybès galètų naudotis tarptautiniais vandens keliais, kurie jungia dvi jūras, nepaisant to, kad juos gali kirsti kariaujančios valstybès laivai, kariai ir kt., tačiau suverenios pakrantės valstybès, kurios jurisdikcijoje yra tarptautiniai vandens keliai, neutralitetui įtakos neturi ${ }^{15}$. Asmenų ir laivų judejjimui buvo taikomas nediskriminacijos principas. Kiekviena valstybè galèjo džiaugtis, jog šiuo atveju jos piliečiams, turtui ir laivams taikomas visiškos lygybės principas; teisės ị perplaukimą nereikejjo ịtvirtinti abipusėse sutartyse ${ }^{16}$.

Taip pat reikia pažymėti, kad šioje byloje teisejjas Schuckingas išdèste atskirają nuomonę, kad teisè į laisvą plaukimą per Kylio kanalą yra servitutas, kuris turi būti aiškinamas griežtai: „Teise laisvai kirsti Kylio kanalą ... neabejotinai igyja servitus juris publici voluntaria formą. Ši koncepcija, kuri per amžius ịrodè, kad yra ypatingai naudinga tarptautinëje teisèje, yra, be abejo, šiuo metu ginčytinas dalykas tarp tarptautinès teisės specialistų, bet jos svarba akivaizdžiai padidejo dèl taikos sutarčių sudarymo pasibaigus Pirmajam pasauliniam karui. Šiose sutartyse buvo nustatyta labai daug teisinių situacijų, kurios gali būti laikomos ne kuo kitu, o servitutu tarptautinèje teiseje. ${ }^{\text {"17 }}$ Visos sutartys, susijusios su servitutu, turi būti aiškinamos griežtai servituto prasme, nes jo dèka atsiranda išskirtiné teisè, kuri taikoma užsienio valstybès teritorijoje, ir ji turi kiek įmanoma mažiau riboti tos valstybès suverenitetą ${ }^{18}$.

Autore pritartų ne tik teisèjo Schuckingo atskirajai nuomonei, bet ir daugumos tarptautinès teisés specialistų, tokių kaip F. A. Vali, H. D. Reid ir kt., nuomonei, kad teisè ị laisvą plaukimą visų valstybių laivams tarptautiniais vandens keliais, kaip Kylio, Sueco ar Panamos kanalais, sudaro tarptautinị servitutą ${ }^{19}$. Šiuo atveju tarptautinio servituto su-

14 Supra note 7, 48 para.

15 Feinaugle, C., supra note 9.

16 Lagoni, R. Kiel Canal. 2009, Max Planck Encyclopedia of Public International Law [interaktyvus]. [žiūrèta 2013-08-18]. < http://www.mpepil.com/>.

17 McNair, A. D., supra note 10, p. 115.

18 Spiermann, O. Professor Walther Schücking at the Permanent Court of International Justice. European Journal of International Law. 2013, 24(20): 788.

19 Tarptautinèje teisèje yra nusistovèję, kad valstybès, kurios valdo minètus kanalus, turi erga omnes ịsipareigojimus visai tarptautinei bendrijai, t. y. jos ịsipareigoja užtikrinti, kad visų valstybių laivai iggyvendintų savo teisę ị laisvą plaukimą šiais kanalais. Atkreiptinas dėmesys, kad tarptautinis servitutas yra tarptautinès teisès institutas, o erga omnes yra įsipareigojimas tarptautinei bendrijai, kuris gali sudaryti tarptautinio servituto turinị. Taigi ne kiekvienas erga omnes ịsipareigojimas sudaro tarptautinio servituto turinị. 
bjektais, iš vienos pusès, yra Vokietija, o iš kitos pusès - tarptautinè bendrija; tarptautinio servituto objektas yra Kylio kanalas, o jo turinys - teisè plaukti Kylio kanalu ir jo prieigomis laisvai ir atvirai visų tautų komerciniams ir karo laivams taikos su Vokietija metu ir jais naudotis visiškai lygiomis sąlygomis. Vokietija kaip tarnaujanti valstybė yra ipareigota praleisti kitų valstybių kaip dominuojančių valstybių komercinius ir karo laivus. Pastovumo požymį atspinti 1919 metais sudaryta Versalio taikos sutartis, o specialus tikslas yra laivų perplaukimas Kylio kanalu. İsipareigojimai visai tarptautinei bendrijai tarptautinèje teisèje vadinami erga omnes issipareigojimais. Todèl šiuo atveju Vokietijos j̇sipareigojimas leisti kitų valstybių komerciniams ir karo laivams laisvai perplaukti Kylio kanalą Vokietijai reiškia erga omnes įsipareigojimą ir toks įsipareigojimas gali sudaryti tarptautinio servituto turinị.

Dar viena byla, kurioje Tarptautinis Teisingumo Teismas priartejo prie tarptautinio servituto instituto, tačiau jo nenagrinejjo, yra Right of Passage over Indian Territory byla (1960). Portugalijos vyriausybė Tarptautiniam Teisingumo Teismui pateikẻ ieškini Indijai. Portugalijos teritorija, esanti Indijos Peninsulos srityje, yra sudaryta iš trijų rajonų: Goa, Damano ir Diu. Damano rajonas yra visiškai apsuptas Indijos teritorijos, be to, jis yra ir pakrantės rajonas. Portugalija Indijos teritorijoje turi du anklavus - Dadrą ir Nagar Haveli. Kad šie Portugalijos valdomi anklavai galètų susisiekti tarpusavyje ir su pakrantès Damano rajonu, iškilo klausimas dẻl Portugalijos teisès ị laisvą perejjimą per Indijos teritoriją ir su šia teise susijusį Indijos ịsipareigojimą. Ieškinyje teigiama, kad $1954 \mathrm{~m}$. liepos mèn. Indijos vyriausybė, priešingai nusistovejusiai praktikai, kliudè Portugalijai igyvendinti teisę i perèjimą. Atviros kompanijos, kuri buvo vykdoma nuo 1950 metų, tikslas buvo aneksuoti Portugalijos teritorijas. Indija, be abejo, neigè tai. Vadovaujantis ieškiniu, anklavai Dadra ir Nagar Havelis buvo visiškai atkirsti nuo likusios Portugalijos teritorijos, todèl Portugalų valdžia negalèjo ịgyvendinti savo suverenių teisių šiuose anklavuose ${ }^{20}$.

Ieškinyje Portugalija pareiškè, kad teisè ị perejjimą per Indijos teritoriją tarp Damano ir Dadros ir Nagar Havelio anklavų bei tarp šių anklavų būtų išplèsta taip, kad galètų igyvendinti savo suverenitetą anklavuose, kuris dabar priklauso nuo Indijos teisès reguliuoti ir kontroliuoti perejjimą. Ieškinyje taip pat teigiama, kad Indija, iggyendindama savo galias reguliuoti ir kontroliuoti savo teritoriją, turi būti ịpareigota nekliudyti būtino perèjimo tam, kad Portugalija galètų igyvendinti savo suverenitetą anklavuose ${ }^{21}$.

Portugalija savo ieškinị dèl teisès ị perèjimą formulavo vadovaudamasi vietiniu papročiu. Indija tam prieštaravo teigdama, kad joks vietinis paprotys negali atsirasti tik tarp dviejų valstybių. Teismui buvo neaišku, kodèl privalo būti daugiau nei dvi valstybès, tarp kurių gali susiformuoti vietinis paprotys. Teismas nemato priežasties, kodèl ilgai taikyta praktika tarp dviejų valstybių, kurioms priimtina reguliuoti savo tarpusavio santykius, neturètų suformuoti pagrindų dvišalèms teisèms ir pareigoms tarp dviejų valstybių atsirasti $^{22}$.

Teismas priejo prie išvados, kad britų ir vèlesnio valdymo laikotarpiu privatiems asmenims, civiliams pareigūnams ir prekèms egzistavo nuolatinè ir vienoda praktika, lei-

20 Case Concerning Right of Passage Over Indian Territory (Portugal v. India). 1960, I. C. J. 6.

21 Ibid.

22 Ibid. 
džianti laisvą perejimą tarp Damano ir anklavų. Ši praktika, nepaveikta besikeičiančių režimų, taikyta ilgiau nei visą amžių, kol Indija tapo nepriklausoma valstybe. Teismas, atsižvelgdamas ị visas bylos aplinkybes, nustaté, kad nusistovèjusi praktika šalims buvo priimtina bei iš šios praktikos kilo teisè ir su ja susijęs j̦sipareigojimas ${ }^{23}$.

Teismas laikosi nuomonès, kad karinių pajėgų, karo policijos, ginklų ir amunicijos atžvilgiu nebuvo nustatyta jokios teisès ị praẻjimą Portugalijos naudai, kuri apimtų su šia teise susijusį Indijos ịsipareigojimą. Nusistovejjusi praktika rodo, kad šių kategorijų praleidimas buvo galimas tik gavus britų valdžios leidimą. Tokia pati tvarka buvo ir pasibaigus britų valdymo laikotarpiui ${ }^{24}$.

Portugalija noredama pagrịsti savo ieškinị dèl teisès ị perèjimą vadovavosi bendru tarptautiniu papročiu ir bendraisiais teisès principais, pripažistamais civilizuotų tautų. Galima daryti išvadą, kad nusistovejo praktika tarp britų ir Indijos valdžios, iš vienos pusès, ir Portugalijos, iš kitos pusès, aiškiai suprantama šalims, kuria vadovaujantis Portugalija ịgijo teisę i perèjimą privačiu asmenų, civilių pareigūnų ir prekių atžvilgiu. Teismas nemano, kad būtina nagrinèti, kas šiuo atveju turètų būti taikomas - tarptautinis paprotys ar bendrieji teisès principai, pripažįstami civilizuotų tautų, nes išvada būtų ta pati ${ }^{25}$.

Karinių pajègų, karo policijos, ginklų ir amunicijos atžvilgiu Teismas nustatè, kad praktika, nusistovẻjusi tarp šalių dèl šių kategorijų perèjimo, reikalavo britų arba Indijos valdžios leidimo, todèl Teismui nèra būtinybès apibrěžti, yra ar nèra tarptautinis paprotys ar bendrieji teisès principai, pripažįstami civilizuotų tautų, kuriais Portugalija gali vadovautis palaikydama savo ieškinį dèl teisés ị perejimą šių kategorijų atžvilgiư ${ }^{26}$.

Teismas nagrinėjo konkrečią bylą, turinčią specialių bruožų. Istoriškai šis atvejis apima tokị laikotarpị ir susijęs su regionu, kuriame santykiai tarp kaimyninių valstybių nebuvo reguliuojami aiškiai suformuluotomis taisyklemmis, bet daugiausia buvo valdomi atsižvelgiant ị nusistovejusią praktiką. Todèl Teismas nustaté, kad aiški praktika, nusistovejusi tarp dviejų valstybių, buvo iggvendinta šalių kaip reguliuojanti jų tarpusavio santykius. Teismas privalo aiškiai išskirti, kad nusistovejjusi praktika apibrèžia šalių specialias teises ir įsipareigojimus. Tokia ypatinga praktika turi vyrauti prieš bendrąsias taisykles ${ }^{27}$.

Dèl šių priežasčių Teismas nusprendè, kad:

Portugalija 1954 metais turèjo teisę ì perèjimą ịsiterpiančioje Indijos teritorijoje tarp Dadros ir Nagar Havelio anklavų ir Damano pajūrio rajono ir tarp šių anklavų būtina apimtimi. Dèl to Portugalija turejjo suverenitetą šiuose anklavuose, tačiau buvo priklausoma nuo Indijos ịgyvendinamo reguliavimo ir kontrolès privačių asmenų, civilių pareigūnų ir prekių atžvilgiu;

Portugalija 1954 metais neturejo teisès ị perejimą karinių pajègų, karo policijos, ginklų ir amunicijos atžvilgiu;

24 Ibid.

25 Ibid.

26 Ibid.

27 Ibid. 
Indija neveike priešingai savo įsipareigojimams, kylantiems iš Portugalijos teisès $\mathfrak{i}$ perèjimą privačių asmenų, civilių pareigūnų ir prekių atžvilgiu ${ }^{28}$.

Taigi šioje byloje Teismas priartėjo prie servituto pripažinimo, nors ir netaikè jo spręsdamas Portugalijos ieškinị dèl teisès ị perèjimą per Indijos teritoriją tarp Portugalijos Dadros ir Nagar Havelio anklavų ir Damano rajono. Teismas, nors ir pripažino teisès in rem egzistavimą, tačiau jos nekvalifikavo kaip „servituto“ ir patenkino Portugalijos ieškinị vadovaudamasis vietiniu papročiu. Toliau buvo nuspręsta, kad tokia teisè nèra bendra, nes ji negalèjo būti pritaikoma karinèms pajègoms ar policijai ir šis reguliavimo dalykas pateko ị Indijos reguliavimo ir kontrolès sritị, todèl ši teisè negalèjo būti pripažǐstama servitutu stricto sensu. Teismas pabrèžè, kad suvereniteto teisès gali būti apribotos senatimi arba istoriniu susijungimu. Todèl iškilo klausimas, ar valstybių, kurios yra beveik visos apsuptos kitos valstybės teritorijos, tranzito teisès yra servitutai, ar paprotinès teisès ${ }^{29}$. Svarbu atkreipti dèmesi i teisejjo Fernandeso atskirąją nuomonę šioje byloje. Jis teigia, kad leidimas nesukuria naujos teisès, tokios kaip teisè i perejjimą; leidimas - tai sąlygas nustatantis teisès aktas - kontrolès aktas. Vadinasi, pagrindinis skirtumas tarp tranzito valstybės galių, susijusių su laisvu tranzitu, yra tas, kad valstybė gali išplèsti ar nustatyti tranzito sąlygas, tačiau ne patị tranzitą per $s e^{30}$.

Autorè, kaip ir daugelis kitų šiuolaikinès tarptautinès teisės mokslininkų (F. A. Vali, H. D. Reid, S. K. Verma, C. Feinaugle ir kt.), mano, kad tranzito teisés sudaro tarptautinio servituto turini. Šiuo atveju tarptautinio servituto subjektai yra dvi valstybès - Indija ir Portugalija, objektas - Indijos teritorija, esanti tarp Damano rajono ir Dadros ir Nagar Havelio anklavų, ir Indijos teritorija, esanti tarp Dadros ir Nagar Havelio anklavų, turinys - teisè i perèjimą privačių asmenų, civilių pareigūnų ir prekių atžvilgiu. Šis tarptautinis servitutas turi ir pastovumo požymị, t. y. Teismas, nagrinėdamas bylą, vadovavosi vietiniu papročiu, kuris susiformavo per ilgą laiką. Indijos valstybẻ kaip tarnaujanti valstybẻ buvo ipareigota leisti Portugalijai (dominuojančiai valstybei) iggyvendinti teisę ì perẻjimą privačių asmenų, civilių pareigūnų ir prekių atžvilgiu. Taip pat galima ịvardinti šio tarptautinio servituto specialų interesą, t. y. Portugalijos norą susisiekti su savo teritorijomis ir jose igyvendinti savo suverenitetą. Taigi, nors Teismas ir neišskyrè tarptautinio servituto šioje byloje, tačiau tarptautinio servituto egzistavimą galima ịžvelgti nagrinèjant jo požymius.

\section{Nacionalinių teismų argumentai pripažįstant tarptautinio servituto egzistavimą}

Nors tarptautiniai teismai atsisakè arba nesiryžo pripažinti tarptautinio servituto instituto anksčiau nagrinètose bylose, tačiau nacionaliniai teismai (Kelno Aukščiausia-

28 Supra note 20.

29 Verma, S. K. An Introduction to Public International Law. New Delhi: PHI Learning Pvt. Ltd., 2004, p. 125-126.

30 Pogoretskyy, V. Freedom Of Transit And The Principles Of Effective Right And Economic Cooperation: Can Systemic Interpretation Of GATT Article V Promote Energy Security And The Development Of An International Gas Market? Journal of International Economic Law. 2013, 16(2): 344 . 
sis Teismas ir Indijos Aukščiausiasis Teismas) ṣ̌ insitutą nagrinètose bylose pripažino. Apskritai tarptautinio servituto instituto pripažinimo klausimas nacionalinių teismų praktikoje nèra dažnas reiškinys, todèl autorè nagrinejja tik dvi nacionalinių teismų bylas, susijusias su šiuo institutu.

Pirmoji nacionalinio teismo byla, kuri pripažino tarptautini servitutą, buvo Dutch State Servitude in Prussia byla. Kelno Aukščiausiasis Teismas (toliau - Teismas) 1914 m. balandžio $21 \mathrm{~d}$. prièmé sprendimą dèl geležinkelio kompanijos „Aix-la-Chapelle-Maastricht" - atsakovo. Ieškovas šioje byloje buvo įmone „Thewis“, o Nyderlandų vyriausybè ị bylą buvo įtraukta trečiąa šalimi.

Ieškovas tuo metu nuosavybès teise valdè daug namų Naustrasso miestelyje netoli Hercogenrato (Prūsija) Wendelino gatvèje. Ieškovas pareiškè teismui, kad šie namai patyrè žalą ir jų turtas nuvertėjo dèl Nyderlandų vyriausybės darbų kasykloje, kurioje ji veike nuomininko teisėmis. Ieškovas prašè teismo pripažinti atsakovą kaltu ir ịpareigoti ji sumokèti už patirtą žalą. Atsakovas prieštaravo pateiktam ieškiniui ${ }^{31}$.

Teismas siekè išsiaiškinti, ar nuomininkas eksploatuodamas kasyklą Prūsijos teritorijoje buvo pavaldus Prūsijos teisei, reguliuojančiai darbą kasyklose, ir jo patirta žala turètų būti vertinama atsižvelgiant ị Prūsijos teisę, ar pripažinti patirtą žalą taikant Nyderlandų teisę $e^{32}$.

Teisinius kasybos santykius apibrěže 1816 m. birželio 26 d. Sienos sutartis tarp Prūsijos ir Nyderlandų. Šia sutartimi buvo siekta aiškiai apibrežti sienas tarp dviejų gretimų valstybių ir pašalinti kliūtis, kilusias dèl suvereniteto iggvendinimo tam tikruose rajonuose. Taigi šios sutarties 18 straipsnis nustaté, kad „dalis Kerkradès rajono, esančio dešinėje Aix-la-Chapelle magistralès pusèje, ir Rolduko rajonas, esantis kairèje Vurmo upès pusèje“, yra perleidžiami Prūsijai. Sutarties 19 straipsnyje buvo nustatyta, kad „Kerkradès ir Rolduko rajonų perleidimas Prūsijai nesukels jokios žalos ar nepatogumų eksploatuojant anglių kasyklą". Anksčiau ši kasykla priklausẻ Rolduko rajono vienuolynui. Dabar ir Kerkradès, ir Rolduko rajonai nuomos teisèmis yra valdomi Nyderlandų vyriausybès. Tokiu atveju Nyderlandų vyriausybe „ar jos vietoj teisètas savininkas turi teisę perleistų rajonų dalyse tęsti darbus, naudingus anglių kasybai ar drenažo tikslams. Tačiau nepaisant to, kad inžinieriams yra išleistos instrukcijos, nustatyti mokesčiai ar nustatyta kitokia atsakomybė, tai negali Prūsijos vyriausybei kliudyti ar uždrausti anglių kasybą ar iškelti ị paviršių iškastas anglis, taip pat negali sudaryti kliūčių parduoti iškastas anglis. Prūsijos vyriausybẻ perleistuose rajonuose taip pat negali suteikti lengvatu privatiems asmenims. Esančios lengvatos yra uždraustos pagal teisès aktus ${ }^{\text {“33. }}$.

Šioje byloje iškilo klausimas, ar interesai, kuriuos turèjo Nyderlandų vyriausybė kasykloje, buvo laikomi suteiktomis lengvatomis, kurias reguliavo Prūsijos teisé, ar šiuos interesus priskirti tarptautiniam servitutui, kurio Prūsijos teisè nereguliuoja. Pirmuoju atveju kasybos teisę reguliuotų Prūsijos privatinè teisé, o antruoju atveju - tarptautiné teisè. Teismas prièmè štai tokị sprendimą:

31 Case of Dutch State Servitude in Prussia. Supreme Court of Cologne, VII Civil Division, April 21,1914 [interaktyvus]. [žiūrèta 2011-03-29]. <http://www.jstor.org/pss/2187316>.

32 An International Servitude. The American Journal of International Law. 1914, 8(4): 858.

33 Supra note 31. 
„Trečioji šalis pateikè pareiškimą, kuriame teigia, kad turi būti atsižvelgta į sienos sutartị tarp Prūsijos ir Nyderlandų, kurios susitarimo prigimtis yra tarptautinè teisè ir pagal kurią dviejų kaimyninių valstybių teritorinis suverenitetas buvo abipusiškai apibrèžtas. Kerkradès ir Rolduko rajonų sritys perejjo Prūsijai, tačiau Nyderlandų vyriausybė išsaugojo teisę tęsti kasybą perleistose srityse. Taigi, jei trečioji šalis teisingai teigia, Prūsijos Nyderlandų vyriausybei suteikta kasybos lengvata negalèjo būti suteikta pagal Prūsijos civilinę teisę, o tai reiškia, kad tam tikros suverenios teisès perleistose srityse kyla iš teritorinio suvereniteto. Teismas sprendè klausimą, kokia apimtimi galioja teisè ị anglių ir kitų mineralų kasybą šiose srityse, jei dalis teritorinio suvereniteto lieka Nyderlandams. Dèl šio fakto iškilo tarptautinio servituto klausimas, dèl kurio Nyderlandams kaip valstybei buvo suteikta kasybos teisè šiose srityse, kuriose galiojo jos pačios įstatymų leidžiamoji valdžia ir policijos priežiūra; tai reiškia, kad ji turèjo realias suverenias teises, kurios galiojo objektui, esančiam kitos valstybès teritorijoje. ${ }^{\text {"34 }}$

Panašu, kad šis sprendimas yra aiškus tarptautinio servituto pripažinimas. Esminis jo teisinio statuso elementas yra tas, kad valstybè, kurios naudai yra suteiktas tarptautinis servitutas, naudojasi savo teisèmis kaip suverenas ir jos yra suteiktos iš suteikiančiojo suvereniteto $^{35}$. Autorè pritaria Teismo nuomonei, kad šioje byloje buvo aiškus tarptautinis servitutas. Autorè taip pat sutinka, kad tarptautinis servitutas yra susijęs su suverenitetu, tačiau nesutinka, kad Nyderlandams kaip dominuojančiai valstybei buvo perleista dalis Prūsijos suvereniteto. Vèliau tarptautiniai teismai pripažino, kad tarptautinio servituto atveju tarnaujanti valstybė neperduoda dominuojančiai valstybei savo suvereniteto dalies, o tik leidžia naudotis tam tikromis suvereniomis teisemis, kylančiomis iš suvereniteto. Taigi Nyderlandams buvo leista naudotis kai kuriomis suvereniomis teisėmis, kylančiomis iš Prūsijos teritorinio suvereniteto. Taip pat reikia pažymėti, kad tarptautinị servitutą ryžosi pripažinti ne tarptautinis, o nacionalinis teismas.

I šią bylą labai panaši North Atlantic Coast Fisheries byla (1910 m.), tik ten iškilo klausimas, ar Jungtinių Amerikos Valstijų naudojimasis žvejybos laisve Didžiajai Britanijai priklausančiuose vandenyse sudaro tarptautinị servitutą. Autorès nuomone, Nuolatinis arbitražo teismas nepateike svarių įrodymų nepripažindamas tarptautinio servituto egzistavimo šiuo atveju. Tokie nepripažinimo argumentai, kaip kad tarptautinis servitutas, yra mažai susiję su suvereniteto principu ir tarptautinès teisès specialistų vertintini kritiškai, nes, autorès nuomone, tarptautinio servituto egzistavimas priklauso nuo to, ar galima juvardinti jo požymius, ar ne.

Su tarptautinio servituto pripažinimu susijusi ir $1990 \mathrm{~m}$. Union of India v. Sukumar Sengupta byla, kurioje sprendimą prièmè kitas nacionalinis teismas - Indijos Aukščiausiasis Teismas.

1947 metais Indijos nepriklausomybès aktu buvo ịkurtos dvi nepriklausomos valstybės Indija ir Pakistanas. Sudaryta Sienų komisija turejo nustatyti šių dviejų valstybių sienas. Po padalijimo tam tikra Indijos teritorija tapo anklavais Rytų Pakistane ir, atvirkščiai, tam tikra Rytų Pakistano teritorija tapo anklavais Indijos teritorijoje. Dehagramas ir Angarpota - tai du Pakistano anklavai Indijos teritorijoje ${ }^{36}$. 
1958 metais Indijos ir Pakistano ministrai pirmininkai pasirašė sutartị, pagal kurią pasidalijo Berubari Sąjungą Nr. 12, kuri buvo laikoma Vakarų Bengalijos provincija, ir pasikeitè anklavais, esančiais Indijos ir Pakistano teritorijose ${ }^{37} .1974$ metais buvo pasirašyta sutartis tarp Indijos ir Bangladešo ministrų pirmininkų. Ši sutartis nustatė, kad Indija išsaugos pusę Berubari Sąjungos Nr. 12 teritorijos, kuri pagal 1958 metų sutartị turèjo būti perleista Pakistanui, o Bangladešas išsaugos Dahagramo ir Angarpotos anklavus, kurie anksčiau priklausẻ Pakistanui. Bangladešo valstybė susikūrẻ 1971 metais ir apėmè teritoriją, kuri buvo žinoma kaip Rytų Pakistanas arba Rytų Bengalas. Šiuo susitarimu Indija taip pat išnuomojo Bangladešui mažą teritoriją, vadinamą Tin Bigha, neribotam laikui, kad Dahagramo ir Angarpotos anklavai galètų susisiekti su Panbari Mouza teritorija, priklausančia Bangladešui. 1974 metais sutartis taip ir neįsigaliojo ${ }^{38}$.

1982 metų sutartimi tarp Indijos ir Bangladešo buvo pasiektas susitarimas dèl sąlygų, kuriomis Indija neribotam laikui išnuomojo Tin Bigha teritoriją, kad Bangladešo valstybė galètų igyvendinti savo suverenitetą Dahagramo ir Angarpotos teritorijose. Buvo sutarta, kad 1982 metų sutartis bus ankstesnès 1974 metų sutarties dalis. Taip pat buvo sutarta, kad išnuomotoje teritorijoje suverenitetas ir toliau priklausys Indijai, tačiau Bangladešas netrukdomas valdys ir naudosis šia teritorija. 1982 metų sutarties 4 ir 5 straipsniai nustatè, kad Indija ir Bangladešo valstybès viena kitai ịsipareigojo, kad tiek Indijos, tiek Bangladešo piliečiai, įskaitant policijos pajègas, pusiau karines ir karines pajègas kartu su ginklais, karinėmis priemonèms ir atsargomis turi teisę laisvai ir nevaržomai judèti išnuomotoje teritorijoje. Nereikalaujama, kad tokie Bangladešo keliautojai turètų pasą ar kitą kelionès dokumentą. Indijos ir Bangladešo prekès taip pat yra laisvai gabenamos išnuomotoje teritorijoje. Iš Bangladešo nereikalaujama mokèti jokių muitų ar tranzito mokesčių. Indija gali išnuomotoje teritorijoje statyti geležinkelị arba tiesti požeminị tunelį, tačiau tai neturi trukdyti Bangladešo piliečių ir prekių laisvam ir nevaržomam judejjimui. Šios sutarties 9 straipsnis įtvirtino, kad nustačius teisès pažeidimą išnuomotoje teritorijoje bus taikoma Indijos arba Bangladešo nacionalinè teisè priklausomai nuo to, kurios valstybès pilietis padarė pažeidimą. Ivykus incidentui, kuris apima abi valstybes, priklausomai nuo aplinkybių bus imamasi veiksmų atkurti teisę ir tvarką. Jei pažeidimą padarys Indijos pilietis ir bus sulaikytas Bangladešo teisèsaugos pareigūnų, jis nedelsiant bus perduotas Indijai ir, atvirkščiai, jei pažeidimą padarys Bangladešo pilietis ir bus sulaikytas Indijos teisèsaugos pareigūnų, jis nedelsiant bus perduotas Bangladešui. Pagal šią sutartị buvo numatyta, kad Indija išlaikys likusią jurisdikciją išnuomotoje teritorijoje $\mathrm{e}^{39}$.

Šioje byloje buvo remtasi tarptautinès teisès mokslininko D. P. O. Connello nuomone, kad vienos iš paprotinių teisès normų, ribojančių suverenias teises, yra servitutai. Servitutai yra instruktyvūs, kai kalbama apie bendrus klausimus ar paprotinès teisès normas suvaržančias suverenias teises gretimų valstybių naudai. Tokios sutartys, kaip pasirašytos tarp Indijos ir Bangladešo, išskyrus žvejybos atvejus, yra servituto pavyzdžiai, nes paprastai jie yra susiję su laisvu perẻjimu ar tranzitu ${ }^{40}$.

$\begin{array}{ll}37 & \text { Supra note } 36 . \\ 38 & \text { Ibid. } \\ 39 & \text { Ibid. } \\ 40 & \text { Ibid. }\end{array}$


Nenuginčijamas argumentas yra tas, kad valstybė turi priejimo teisę prie savo anklavų per užsienio valstybės teritoriją, ir jie egzistuoja todèl, kad jiems yra suteikti vadinamieji būtinieji patogumai, todèl visi anklavai yra servitutai. Tačiau Tarptautinis Teisingumo Teismas Right of Passage over Indian Territory byloje teisès i perejimą nepripažino tarptautiniu servitutu, nes vadovavosi vyraujančia praktika ir jam nebuvo jokios būtinybès vadovautis tarptautine teise. Faktiškai yra taip, kad laisvas perejjimas reiškia ribotą perèjimą, nes valstybe், kuriai priklauso teritorija, gali reguliuoti, kaip kitai valstybei igyvendinti savo teises ${ }^{41}$.

Indijos Aukščiausiasis Teismas pripažino, kad Bangladešas pagal tarptautinę teisę ir nusistovejusias paprotinès teisès normas turi teisę susisiekti su Dahagramo ir Angarpotos anklavais per Indijos teritoriją. Ši tarptautine praktika ir paprotinès teisès normos buvo ịtvirtintos sutartyse. Taip pat reikia pažymėti, kad Bangladešui buvo suteikta teisė ì perėjimą karinėms, pusiau karinèms, policijos pajejgoms kartu su ginklais ir kitokiomis karinėmis priemonemis per Tin Bigha teritoriją. Taigi šios Bangladešui suteiktos lengvatos apima tarptautinius servitutus Indijos teritorijoje, tačiau servituto pripažinimas nepaneigia Indijos suvereniteto. Indijos suverenitetui šioje teritorijoje buvo nustatyti tam tikri apribojimai, kad Bangladešas minèta teritorija naudotųsi savo interesams. Reikia pažymėti, kad šiuos apribojimus nusistatė pati Indija. Sąvoka „servitutas“ reiškia prisiimtą apribojimą, o servituto suteikimas nereiškia teritorijos perleidimo. Žemesnès instancijos teismas nesprende ginčo dèl 1982 metų sutarties 9 straipsnyje vartojamo žodžių junginio „likusi jurisdikcija“ todèl, kad Indija išlaiko šioje teritorijoje savo suverenitetą, nors de facto ir realus suverenitetas buvo perduotas Bangladešui. Aukščiausiasis Teismas sutiko su žemesnès instancijos teismo sprendimu, kad Tin Bigha teritorija nebuvo perleista Bangladešui pagal 1974 ir 1982 metų sutartis, taip pat nebuvo jokio suvereniteto atsisakymo ${ }^{42}$.

Taigi šioje byloje Indijos Aukščiausiasis Teismas apibūdino teritorinị patogumą, suteiktą Bangladešui naudotis Indijos vieta, vadinama Tin Bigha, kaip servitutą tarptautinejje teisèje. Tarptautinès teisès mokslininko S. K. Verma nuomone, šis teritorinis patogumas laikui bėgant subręs tapti senaties teise ${ }^{43}$.

Autorè sutinka su šioje byloje Indijos Aukščiausiojo Teismo išdèstytais argumentais, kodèl Bangladešui priklausanti teisè ị priejjimą prie savo anklavų sudaro tarptautinị servitutą. Tarptautinio servituto institutui tarptautineje teisejje šis teismo sprendimas svarbus tuo, kad nacionalinis teismas teisę i perejjimą, kuri sudaro tarptautinio servituto turinị, ivvardijo kaip teritorini patogumą.

\section{Išvados}

1. Apibendrinant nagrinètų tarptautinių teismų bylas galima daryti išvadą, kad tarptautiniai teismai atsisake pripažinti tarptautini servitutą arba iš viso atsisakè ji nagrinèti pateikdami bendrą argumentą, kad suteiktos teisès ar laisvès nebuvo tiesiogiai îvardi-

\footnotetext{
41 Supra note 36.

42 Ibid.

43 Verma, S. K., supra note 29, p. 126-127.
} 
jamos sutartyse kaip tarptautiniai servitutai. Pavyzdžiui, tarptautiniai teismai atsisake pripažinti tarptautinị servitutą, nes jie nebuvo tiesiogiai įvardijami šiose sutartyse: 1818 metų sutartis tarp Jungtinių Amerikos Valstijų ir Didžiosios Britanijos dèl žvejybos laisvès (North Atlantic Coast Fisheries byla), o SS „Wimbledon“ byloje iš viso teismas atsisake nagrinèti tarptautinị servitutą, t. y. nei ji pripažino, nei paneigé, nes 1919 metų Versalio taikos sutartyje apie ji taip pat nebuvo tiesiogiai užsiminta. Right of Passage over Indian Territory byloje buvo remtasi net ne sutartimi, o vietiniu papročiu, todel akivaizdu, kad ir šiuo atveju tarptautinis servitutas niekur nebuvo tiesiogiai įvardintas. Visai kita situacija yra nacionaliniams teismams nagrinejjant bylas, susijusias su tarptautiniu servitutu. Žinoma praktika nèra gausi, tačiau nacionaliniai teismai remdamiesi tarp valstybių pasirašytomis sutartimis, kaip, pavyzdžiui, 1816 metų Sienos sutartimi tarp Prūsijos ir Nyderlandų (Dutch State Servitude in Prussia byla) arba 1982 metų sutartimi tarp Indijos ir Bangladešo (Union of India $v$. Sukumar Sengupta byla), nustate, kad tose sutartyse įtvirtintos tesès ar teritoriniai patogumai sudaro tarptautinị servitutą. Autorès nuomone, tarptautinio servituto egzistavimas priklauso ne nuo to, ar jis yra įtvirtintas sutartyje, ar egzistuoja papročio pagrindu, o nuo to, ar galima ịvardinti jo požymius toje situacijoje, ar ne.

2. Galima pateikti ir kitus tarptautinių teismų argumentus nepripažizstant tarptautinio servituto egzistavimo:

North Atlantic Coast Fisheries byloje Nuolatinis arbitražo teismas nagrinejo tarptautinį servitutą, tačiau žvejybos laisvę, suteiktą Jungtinèms Amerikos Valstijoms, pripažino ne tarptautiniu servitutu, o tik ekonomine laisve. Be to, Teismas mané, kad tarptautinis servitutas yra mažai susijęs su suvereniteto principu ir nèra pakankamai remiamas tarptautinès teisès specialistų. Dėl šios nuomonės Teismas ne kartą buvo kritikuotas žymių tarptautinès teisès mokslininkų veikaluose. Autorès nuomone, tarptautinių teismų pateikti argumentai, nepripažistantys ar atsisakantys pripažinti tarptautinio servituto egzistavimą, vertintini kritiškai, nes tarptautinio servituto egzistavimas priklauso nuo to, ar galima įvardinti jo požymius, ar ne. Autore daro išvadą, kad šioje byloje egzistavo tarptautinis servitutas, t. y. buvo aiškūs tarptautinio servituto subjektai, t. y. Jungtinès Amerikos Valstijos - dominuojanti valstybè, arba, kitaip tariant, naudos gaveja, ir Didžioji Britanija - tarnaujanti valstybè. Tarptautinio servituto objektas buvo 1818 metų sutartimi nustatyti Kanados ir Niufaundlendo vandenys, o jo turinys - ta pačia sutartimi nustatyta laisvè žvejoti Jungtinių Amerikos Valstijų gyventojams. Ši laisvė egzistavo gana seniai, t. y. Teismas pažymėjo, kad ji atsirado 1783 metais, o vẻiau pakartota 1818 metų sutartyje, todèl tarptautinị servitutą galima ịvardinti kaip ilgalaikį ir pastovų. Tarptautinis servitutas turi ir ketvirtąji požymị, t. y. Jungtinès Amerikos Valstijos ịgyvendino suteiktą žvejybos laisvę Didžiajai Britanijai priklausiusiuose vandenyse. Be abejo, ši laisvė yra susijusiu su specialiu tikslu - pagauti žuvies.

SS „Wimbledon“ byloje Nuolatinis Tarptautinis Teisingumo Teismas paliko atvirą klausimą, ar teisè ị laisvą plaukimą per Kylio kanalą sudaro tarptautinị servitutą, nors šios bylos teisejjas M. Schuckingas išdèstė savo atskirąją nuomonę, kad tai yra servitutas, kuris turi būti aiškinamas griežtai. Autorès nuomone, tarptautinio servituto egzistavimą šioje byloje rodo šie požymiai: tarptautinio servituto subjektai, iš vienos pusès, yra Vokietija, o iš kitos pusès - tarptautinè bendrija; tarptautinio servituto objektas yra Kylio kanalas, o jo turinys - teise plaukti Kylio kanalu ir jo prieigomis laisvai ir atvirai visų tautų komerciniams ir karo laivams taikos su Vokietija metu ir jais naudotis visiškai lygiomis sąlygomis. 
Vokietija kaip tarnaujanti valstybė yra įpareigota praleisti kitų valstybių kaip dominuojančių valstybių komercinius ir karo laivus. Pastovumo požymį atspinti 1919 metais sudaryta Versalio taikos sutartis, o specialus tikslas yra laivų plaukimas Kylio kanalu.

Right of Passage over Indian Territory byloje Tarptautinis Teisingumo Teismas vèlgi nesiejo Portugalijai priklausiusios teisès ị perejjimą su tarptautinio servituto institutu, nors ir pripažino daiktinès teisès egzistavimą. Autorès nuomone, šiuo atveju tarptautinio servituto subjektai yra dvi valstybès - Indija ir Portugalija, objektas - Indijos teritorija, esanti tarp Damano rajono ir Dadros ir Nagar Havelio anklavų, ir Indijos teritorija, esanti tarp Dadros ir Nagar Havelio anklavų, turinys - teisè i perejjimą privačių asmenų, civilių pareigūnų ir prekių atžvilgiu. Šis tarptautinis servitutas turi ir pastovumo požymį, t. y. Teismas, nagrinėdamas bylą, vadovavosi vietiniu papročiu, kuris susiformavo per ilgą laiką. Indijos valstybė kaip tarnaujanti valstybė buvo ịpareigota Portugalijai (dominuojančiai valstybei) leisti iggvendinti teisę ị perèjimą privačių asmenų, civilių pareigūnų ir prekių atžvilgiu. Taip pat galima įvardinti šio tarptautinio servituto specialų interesą, t. y. Portugalijos norą susisiekti su savo teritorijomis ir jose igyvendinti savo suverenitetą.

3. Nacionalinių teismų praktika tarptautinio servituto pripažinimo klausimu nèra gausi. Dutch State Servitude in Prussia byloje, kurią nagrinėjo Kelno Aukščiausiasis Teismas, pripažino, kad Nyderlandų Vyriausybei priklausančios kasybos teisès Prūsijos teritorijoje sudaro tarptautinį servitutą, t. y. Nyderlandų vyriausybès suvereni teisé, kuri galiojo objektui, esančiam kitos valstybès teritorijoje. O Union of India v. Sukumar Sengupta byloje Indijos Aukščiausiasis Teismas pripažino teisę ì perejimą (ją dar ịvardijo būtinuoju patogumu arba lengvata), suteiktą Bangladešui naudotis ir valdyti Indijai priklausančią Tin Bigha teritoriją kaip servitutą tarptautinèje teisèje.

\section{Literatūra}

An International Servitude. The American Journal of International Law. 1914, $8(4)$.

Boczek, B. A. International Law - A Dictionary. USA: Scarecrow Press, 2005.

Case Concerning Right of Passage Over Indian Territory (Portugal v. India). 1960, I. C. J. 6.

Case Of Dutch State Servitude in Prussia. Supreme Court of Cologne, VII Civil Division, April 21, 1914 [interaktyvus]. [žiūrèta 2011-03-29]. <http://www. jstor. org/pss/2187316>.

Case Of The SS „Wimbledon“, P.C.I.J., ser. A, No. 1, 1923.

Feinaugle, C. The Wimbledon. 2008, Max Planck Encyclopedia of Public
International Law [interaktyvus]. [žiūrèta 2011-02-01]. <http://www.mpepil. $\mathrm{com} />$.

Griškevičienè, I. Tarptautinio servituto institutas tarptautineje teisejje: teoriniai aspektai. Socialiniu mokslu studijos. 2011, 3(4): 1461-1477.

Kelsen, H. Principles of International Law. 5 th ed. New Jersey: The Lawbook Exchange Ltd, 2003.

Lagoni, R. Kiel Canal. Max Planck Encyclopedia of Public International Law [interaktyvus]. 2009 [žiūrèta 201308-18]. <http://www.mpepil.com/>.

McNair, A. D. So-Called State Servitudes. British Year Book of International Law 6 Brit. Y. B. Int'l L. 111, 1925. 
North Atlantic Coast Fisheries Tribunal of Arbitration constituted under a Special Agreement signed at Washington, January 27th, 1909, between the United States of America and Great Britain, Permanent Court of Arbitration, the Hague, 1910 [interaktyvus]. [žiūrèta 2011-04-05]. <http://www.pca-cpa.org>. Pogoretskyy, V. Freedom of Transit and the Principles of Effective Right and Economic Cooperation: Can Systemic Interpretation of Gatt Article V Promote Energy Security and the
Development of an International Gas Market? Journal of International Economic Law. 2013, 16(2).

Richards, E. The North Atlantic Coast Fisheries Arbitration. Journal of the Society of Comparative Legislation. 1910, 11(1).

Verma, S. K. An Introduction to Public

International Law. New Delhi: PHI Learning Pvt. Ltd., 2004.

Union of India and Ors vs. Sukumar

Sengupta and Ors, AIR 1990 SC 1692.

\title{
RECOGNITION OF INTERNATIONAL SERVITUDE IN INTERNATIONAL COURT CASES
}

\author{
Inga Griškevičienè
}

Mykolas Romeris University, Lithuania

Summary. The institute of international servitude is recognized in the theory of International Law, despite the fact that this category is still controversial. The international servitude has been transferred from private law and originated during the feudal time. In this article, the author scrutinizes the international servitude, following international and national judicial decisions.

The international servitude was scrutinized for the first time in the North Atlantic Coast Fisheries case by the Permanent Court of Arbitration in 1910. In this case, the Court decided that the liberty to fish granted to the United States of America by Great Britain was a purely economic right and it did not constitute an international servitude. The Court decided that the doctrine of the international servitude is being but little suited to the principle of sovereignty and has found little support from modern publicists. The Court was criticised for this view many times by the modern publicists of International Law.

In the case of Dutch State Servitude in Prussia judged by the Supreme Court of Cologne, it was recognized that the mining rights which belonged to the Government of Holland in the territory of Prussia constituted the international servitude. It was the first time when a national court recognized the existence of the international servitude in International Law.

The Permanent Court of International Justice in the SS Wimbledon case did not recognize the right of the S.S. "Wimbledon" to free passage through the Kiel Canal under the terms of Article 380 of the Treaty of Versailles as the international servitude. The judge M. Schücking in the Dissenting Opinion stated that this situation concerned servitudes and must be interpreted restrictively. 
The International Court of Justice in the Right of Passage over Indian Territory case did not recognized the right to passage over Indian territory for Portugal as the international servitude, but stated it as real right. The Supreme Court of India in the Union of India v. Sukumar Sengupta case stated it as the same right to free passage over Teen Bigha territory, which was granted to Bangladesh by India as the international servitude.

International institutions did not recognize the international servitude in their decisions, but national courts did recognize it as an inevitable necessity, which was obvious consideration in some cases.

Keywords: international servitude, a dominant state, a servant state, right in rem.

Inga Griškevičienė, Mykolo Romerio universiteto Teisès fakulteto Tarptautinès ir Europos Sąungos teisès instituto lektorè, doktorantė. Mokslinių tyrimų kryptis: tarptautinè teisè.

Inga Griškevičienė, Mykolas Romeris University, Faculty of Law, Institute of International and European Union Law, Lecturer, Doctoral student. Research interest: international law. 